\title{
PENGARUH PEMBERIAN TIMBAL (Pb) TERHADAP MORFOLOGI DAN KADAR TERSERAPNYA TIMBAL (Pb) PADA DAUN BAYAM (Amaranthus tricolor L.) DALAM SKALA LABORATORIUM
}

\author{
Wirdati Irma*, Nurmei Susanti
}

\author{
Program Studi Bilogi Fak.MIPA dan Kesehatan Universitas Muhammadiyah Riau
}

\begin{abstract}
ABSTRAK
Penelitian ini dilakukan pada bulan Mei-Juni 2013. Penelitian ini bertujuan untuk melihat pengaruh timbal (Pb) dengan konsentrasi berbeda terhadap bentuk morfologi daun bayam cabut serta mengetahui kadar timbal yang terakumulasi pada daun bayam cabut dengan 3 konsentrasi $\mathrm{Pb}$ yang berbeda, yaitu 1 ppm, 3 ppm, 5 ppm dan kontrol dalam skala laboratorium. Metode penelitian secara eksperimen di laboratorium. Hasil penelitian menunjukkan bahwa dari analisis $\mathrm{Pb}$ yang dilakukan, bayam $\mathrm{Pb} 1 \mathrm{ppm}$ terjadi perubahan morfologi hanya pada warna daun dan permukaan daun. Pada bayam $\mathrm{Pb} 3$ ppm dan 5 ppm terjadi perubahan morfologi pada semua karakteristik daun. Kadar timbal pada B3 (5 ppm) menunjukkan hasil yang tinggi yaitu 1,13 ppm, sedangkan B2 (3 ppm) 0,84 ppm dan B1 (1 ppm) 0,30 ppm. Kerusakan terlihat yang diakibatkan dari ketiga konsentrasi tersebut beragam, makin tinggi konsentrasi $\mathrm{Pb}$, kerusakan tanaman pun semakin besar.
\end{abstract}

Kata kunci: Bayam, Morfologi, Daun, Timbal $(\mathrm{Pb})$, Karakteristik.

\section{PENDAHULUAN}

Bayam adalah tanaman yang termasuk dalam Famili Amaranthaceae, dengan nama latin Amaranthus sp yang merupakan tanaman perdu dan semak. Bayam memiliki banyak jenis, ada yang dibudidayakan dan ada yang tidak dibudidayakan. Fungsi bayam sangat beragam dan bermanfaat, di antaranya bayam dapat memperbaiki daya kerja ginjal, akarnya dapat digunakan untuk mengobati penyakit disentri, mempercepat pertumbuhan sel, serta dapat mempercepat proses penyembuhan bagi orang yang sedang menjalani perawatan setelah sakit. Bayam juga dapat digunakan sebagai bahan untuk masakan seperti gado-gado, sayur bening, pecel, dan lain-lain. Daun bayam juga dapat dimanfaatkan untuk membuat keripik bayam yang rasanya gurih dan renyah (Tafajani, 2011).

Bayam (Amaranthus tricolor L.) merupakan tanaman yang daunnya biasa dikonsumsi sebagai sayuran, karena memiliki tekstur yang lunak. Kandungan seratnya pun cukup tinggi sehingga dapat membantu memperlancar proses pencernaan. Bayam kaya akan garam mineral seperti kalsium, fosfor, dan besi. Bayam juga mengandung beberapa macam vitamin, seperti vitamin A, B, dan C.

Sayur ini juga mempunyai nilai ekonomis tinggi dibandingkan dengan beberapa jenis bayam lainnya. Hal ini disebabkan besarnya permintaan yang cukup tinggi dari beberapa supermarket, hotel dan restoran. Bayam jika dipelihara dengan baik, dan syarat tumbuhnya terpenuhi, maka dapat diperoleh produksi 3,5-5 ton per hektar (Sunarjono, 2013 dan Tafajani, 2011).

Tanaman bayam merupakan salah satu jenis sayuran komersial yang mudah diperoleh di setiap pasar, baik pasar tradisional maupun pasar swalayan. Umumnya tanaman bayam dikonsumsi bagian daun dan batangnya. Ditinjau dari kandungan gizinya, bayam merupakan jenis sayuran hijau yang banyak manfaatnya bagi kesehatan, terutama bagi anak-anak dan wanita hamil. Di dalam 5 daun bayam terdapat cukup banyak kandungan protein, kalsium, zat besi, dan vitamin yang dibutuhkan oleh tubuh manusia (Bandini dan Azis, 2005).

Di Indonesia produk bayam saat ini sangat berpotensi untuk dikembangkan baik kualitas dan kuantitasnya. Oleh karena itu diperlukan upaya baik dalam bidang peningkatan kualitas dan kuantitas keamanan sayuran segar tersebut, karena pada akhir-akhir ini kasus keracunan logam berat yang berasal dari bahan pangan semakin meningkat jumlahnya.

Timbal $(\mathrm{Pb})$ adalah salah satu logam berat 
yang dapat mempengaruhi tanaman. Logam berat $\mathrm{Pb}$ dapat terserap dalam jaringan tanaman melalui akar dan stomata daun yang akhirnya terjadi gejala klorisis pada ujung sisi daun dan daun menjadi busuk juga rusak. Timbal $(\mathrm{Pb})$ dapat terakumulasi di lingkungan, tidak dapat terurai secara biologis dan toksisitasnya tidak berubah sepanjang waktu.

Timbal $(\mathrm{Pb})$ merupakan logam berat yang sangat beracun pada seluruh aspek kehidupan. Logam $\mathrm{Pb}$ berperan sebagai mobilitas pada proses penyerapan logam dari akar tanaman menuju daun. Pencemaran logam timbal dapat menimbulkan pengaruh negatif pada klorofil karena sebagian besar diakumulasi oleh organ tanaman, yaitu daun, batang, akar dan tanah sekitar tanaman. Tanaman dapat menyerap logam timbal pada saat kondisi kesuburan dan kandungan bahan organik tanah rendah, pada keadaan ini $\mathrm{Pb}$ akan terlepas dari ikatan tanah berupa ion dan bergerak bebas dalam larutan tanah maka akan terjadi serapan $\mathrm{Pb}$ oleh akar tanaman. Kemudian ditransfer ke bagian lain dari tanaman yaitu batang, ranting, dan daun, tapi pada konsentrasi yang tinggi $(100-1000 \mathrm{mg} / \mathrm{kg}$ ) dapat mengakibatkan pengaruh toksik terhadap proses fotosintesis sehingga pertumbuhan akan terhambat (Widowati et al., 2008).

Menurut penelitian yang dilakukan oleh Widowati (2011), adanya logam berat $\mathrm{Pb}$ dapat mempengaruhi bentuk morfologi daun kangkung. Hal ini terlihat dengan penurunan warna hijau pada batang dan daun tanaman yang akhirnya menguning dan mengalami klorisis, serta nekrosis pada ujung dan sisi daun, sayur paling besar mengakumulasi logam $\mathrm{Pb}$, sehingga dapat mengalami perubahan penurunan warna hijau, karena logam dapat menggantikan unsur $\mathrm{Mg}$ dalam klorofil, suatu senyawa yang menyebabkan batang dan daun berwarna hijau.

$\mathrm{Pb}$ bersifat toksik jika terhirup atau tertelan oleh manusia dan di dalam tubuh akan beredar mengikuti aliran darah, diserap kembali di dalam ginjal dan otak, dan disimpan di dalam tulang dan gigi (Cahyadi, 2006). Toksisitas timbal dapat menyebabkan hipertensi. Bahkan tidak hanya itu, Charlena (2004) mengungkapkan bahwa akumulasi logam berat $\mathrm{Pb}$ pada tubuh manusia yang terus menerus dapat mengakibatkan anemia, kemandulan, penyakit ginjal, kerusakan syaraf dan kematian. Pada anak- anak, akumulasi $\mathrm{Pb}$ dapat menurunkan kecerdasan yang dilihat pada angka IQ (Suparwoko, 2008).

Timbal adalah logam yang mendapat perhatian karena bersifat toksik melalui konsumsi makanan, minuman, udara, air, serta debu yang tercemar timbal. Timbal masuk ke dalam tubuh melalui jalur oral, lewat makanan, minuman, pernafasan, kontak lewat kulit, serta kontak lewat mata (Widowati, 2008).

Toksik yang disebabkan oleh logam $\mathrm{Pb}$ dalam tubuh dapat mempengaruhi organ-organ tubuh antara lain sistem saraf, ginjal, sisitem reproduksi, sistem endokrin dan jantung (Suharto, 2005).

Indonesia mempunyai batas maksimum cemaran Timbal $(\mathrm{Pb})$ pada bahan makanan yang ditetapkan oleh Dirjen POM dalam Surat Keputusan Dirjen POM No. 03725/B/SK/VII/89 tentang Batas Maksimum Cemaran Logam dalam sayuran dan hasil olahannya maksimum 2,0 ppm. Sedangkan untuk kandungan $\mathrm{Pb}$ dalam tanah secara alamiah yaitu sebesar 10 ppm (Widiningrum et al., 2007).

\section{METODOLOGI PENELITIAN}

\section{Waktu dan Tempat Penelitian}

Penelitian ini dilaksanakan pada bulan Mei sampai Juni 2013. Tempat penelitian di Laboratorium Biologi Fakultas MIPA dan Kesehatan Universitas Muhammadiyah Riau. Sedangkan untuk pengujian kadar timbal $(\mathrm{Pb})$ dilakukan di Laboratorium Kimia Hasil Perikanan Universitas Riau (UR).

\section{Alat dan Bahan}

a. Alat

Alat untuk membuat larutan $\mathrm{Pb}$ meliputi: beaker glass, gelas ukur $10 \mathrm{ml}$, labu ukur, pipet ukur, buret, batang statif, batang pengaduk, spatula, timbangan, labu kjedhal, kertas saring whatmann no.42, alat tulis dan kertas label. Sedangkan alat untuk di lapangan meliputi: polybag, kantong plastik, gunting, penyemprot (tempat semprotan), botol kecil (tempat larutan $\mathrm{Pb}$ ), cangkul, paranet, tali raffia, palu, paku, literan, pisau, meteran, kamera. Sedangkan alat 
untuk menguji kadar $\mathrm{Pb}$ : 1 set alat AAS (Spektrofotometer Serapan Atom/ASS Varian Spectr-AA3110 Series).

\section{b. Bahan}

Bahan yang digunakan meliputi bayam(Amaranthus tricolor L.) yang telah berumur 2 minggu, tanah sebagai media tanam yang bebas $\mathrm{Pb}(0 \mathrm{ppm})$, larutan $\mathrm{PbNO}_{3}$ (timbal nitrat) cair $1000 \mathrm{ppm}, \mathrm{HNO}_{3}$ (asam sitrat) (p) 65 $\%$, aquades, pupuk NPK, $\mathrm{HClO}_{4} 30 \%$.

\section{Alat dan Bahan}

\section{a. Alat}

Untuk mengetahui pengaruh pemberian timbal $(\mathrm{Pb})$ terhadap morfologi daun bayam (Amaranthus tricolor L.) digunakan metode penelitian secara eksperimen di laboratorium dengan 3 perlakuan, yaitu $\mathrm{Pb} 1 \mathrm{ppm}, \mathrm{Pb} 3 \mathrm{ppm}$, $\mathrm{Pb} 5$ ppm dan tanaman kontrol

\section{Pelaksanaan Penelitian}

Langkah-langkah pelaksanaan penelitian dilakukan sebagai berikut:

a. Dari 40 polybag yang telah dipersiapkan dibagi menjadi sampel untuk 3 perlakuan dan 1 kontrol.

1. Sampel A: terdiri atas 5 sampel bayam dimana untuk perlakuan digunakan larutan $\mathrm{Pb} 1 \mathrm{ppm}$.

2. Sampel B: terdiri atas 5 sampel bayam, dimana untuk perlakuan digunakan larutan $\mathrm{Pb} 3$ ppm.

3. Sampel C: terdiri atas 5 sampel bayam dimana untuk perlakuan digunakan larutan $\mathrm{Pb} 5$ ppm.

4. Sampel D: merupakan sampel bayam yang tidak diberikan $\mathrm{Pb}$ (kontrol) yang terdiri dari 5 polybag.

b. Pemberian larutan $\mathrm{Pb}$ dilaksanakan dengan cara disemprot dan dilakukan $2 \mathrm{x}$ sehari yaitu, pada pukul 07.00 WIB (pagi) dan pukul 06.00 WIB (sore).

c. Air yang digunakan untuk penyemprotan ditambahkan larutan $\mathrm{Pb}$ per konsentrasi sebanyak 1 liter (untuk 2x penyiraman).

d. Khusus untuk tanaman kontrol dan cadangan, air yang digunakan dalam penyiraman tidak ditambahkan larutan $\mathrm{Pb}$.

e. Analisis bentuk morfologi daun dilakukan pada usia bayam 3 mingggu dan analisis konsentrasi $\mathrm{Pb}$ pada daun bayam dilakukan pada saat tanaman telah mencapai usia 5 minggu.

f. Tanaman yang akan dianalisis dipanen dengan cara memotong bagian tangkai daun tanaman bayam.

g. Analisis Morfologi daun bayam yang diamati adalah warna daun, permukaan daun, pangkal daun, ujung daun, tepi daun, dan susunan tulang-tulang daun

2. Kandungan $\mathrm{Pb}$ Yang Terserap Oleh Daun Bayam.

Analisis kandungan $\mathrm{Pb}$ menggunakan AAS (Spektrofotometer Serapan Atom/ASS Varian Spectr-AA3110 Series) dengan metode destruksi basah (Darmono, 1995).

\section{HASIL DAN PEMBAHASAN}

Berdasarkan hasil penelitian yang telah dilakukan hasil yang diperoleh dapat di lihat pada tabel berikut:

1. Perubahan Morfolofi Daun Bayam

Tabel 1. Karakteristik Morfologi Daun Bayam Cabut Hijau pada Usia 3 minggu

\begin{tabular}{|c|c|c|c|c|c|}
\hline No & $\begin{array}{l}\text { Karakteristik } \\
\text { morfologi daun } \\
\text { Bayam }\end{array}$ & Kontrol & $\begin{array}{l}1 \\
\mathrm{ppm}\end{array}$ & $\begin{array}{l}3 \\
\text { ppm }\end{array}$ & $\begin{array}{l}5 \\
\mathrm{ppm}\end{array}$ \\
\hline 1 & Warna daun & $\mathrm{H}$ & HK & HK & HK \\
\hline 2 & $\begin{array}{l}\text { Permukaan } \\
\text { daun }\end{array}$ & $\mathrm{R}$ & TR & TR & TR \\
\hline 3 & Pangkal daun & M & M & $\mathrm{T}$ & $\mathrm{R}$ \\
\hline 4 & Ujung daun & $\mathrm{Rc}$ & $\mathrm{Rc}$ & $\mathrm{T}$ & $\mathrm{R}$ \\
\hline 5 & Tepi daun & $\mathrm{R}$ & $\mathrm{R}$ & TR & TR \\
\hline 6 & $\begin{array}{l}\text { Susunan tulang } \\
\text { daun }\end{array}$ & S & S & $\mathrm{P}$ & $\mathrm{P}$ \\
\hline $\begin{array}{l}\text { Ket } \\
\mathrm{H} \\
\mathrm{M} \\
\mathrm{Rc} \\
\mathrm{S} \\
\mathrm{KH} \\
\mathrm{T} \\
\mathrm{R} \\
\mathrm{TR} \\
\mathrm{P}\end{array}$ & $\begin{array}{l}\text { erangan: } \\
\quad \text { : Hijau } \\
\text { : Membual } \\
\text { : Runcing } \\
\text { : Sempurna } \\
\text { : Hijau Kel } \\
\text { : Tumpul } \\
\text { : Rata } \\
\text { : Tidak Rat } \\
\text { : Putus }\end{array}$ & ningan & & & \\
\hline
\end{tabular}

Pada Tabel 1. dapat dilihat bahwa secara umum terjadi perubahan morfologi daun bayam untuk setiap perlakuan konsentrasi $\mathrm{Pb}$ dibandingkan tanpa perlakuan $\mathrm{Pb}$. Pengaruh tersebut terlihat dengan timbulnya beberapa kerusakan pada morfologi daun bayam seperti pada warna daun, permukaan daun, pangkal daun, tepi daun, dan susunan tulang-tulang daun. 
Adapun perubahan yang terjadi dapat dilihat bahwa karakteristik morfologi daun bayam yang terkontaminasi $\mathrm{Pb}$ dengan perlakuan yang berbeda terjadi perubahan bila dibandingkan dengan tanaman kontrol, ini terjadi pada saat bayam berumur 3 minggu atau setelah 1 minggu disemprotkan timbal $(\mathrm{Pb})$. Perubahan yang terjadi dapat dilihat dari warna daunnya, yang awalnya berwarna hijau berubah menjadi warna hijau kekuningan. Permukaan daun menjadi berubah dan timbul bercak-bercak putih serta ada daun yang bolong. Pangkal daun yang awalnya rata berubah menjadi tumpul.

Kerusakan yang terjadi pada daun bayam yang diberi $\mathrm{Pb} 1 \mathrm{ppm}$ adalah permukaan daun menjadi tidak rata dan timbul bercak-bercak putih, perubahan ini terjadi pada minggu ke-3 pertumbuhan bayam setelah 1 minggu disemprotkan Timbal $(\mathrm{Pb})$, hal ini sesuai dengan hasil penelitian yang dilakukan oleh Onggo (2006) yang menyatakan bahwa penyemprotan dengan konsentrasi rendah, gejala kerusakan awal yang tampak menyebabkan permukaan tanaman berubah. Daun tanaman yang berubah mengakibatkan permukaan daun tidak rata atau rusak, warna daun berubah menjadi hijau kekuningan. Perubahan tersebut dapat dilihat pada gambar berikut:

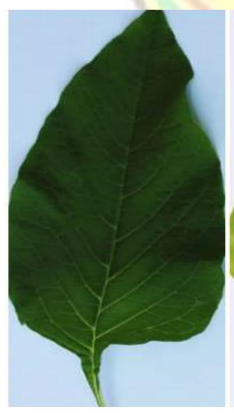

A

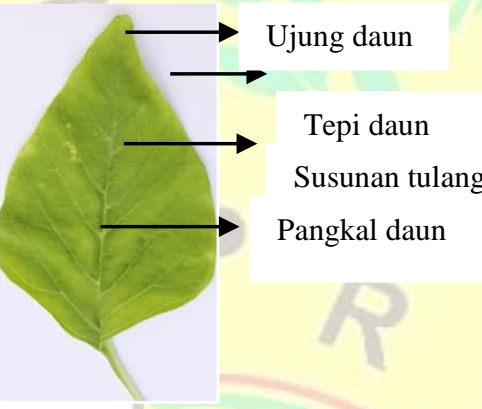

B
Gambar 1. Gambar Bayam control (a) dan denganperlakuan diberi 1 ppm $\mathrm{Pb}(\mathrm{b})$.

Kerusakan daun pada pemberian $\mathrm{Pb} 3 \mathrm{ppm}$ pada minggu ke-3 pertumbuhan bayam setelah 1 minggu disemprotkan $\mathrm{Pb}$ mengakibatkan kerusakan morfologi pada daun tanaman bayam. Kerusakan tersebut adalah terjadinya susunan tulang-tulang daun rusak/tidak sempurna. Hal ini diakibatkan oleh perubahan morfologi pada bagian ujung daun menjadi tumpul, bagian tepi daun berombak/tidak rata, permukaan daun dan warna daun menunjukkan perubahan yang signifikan.

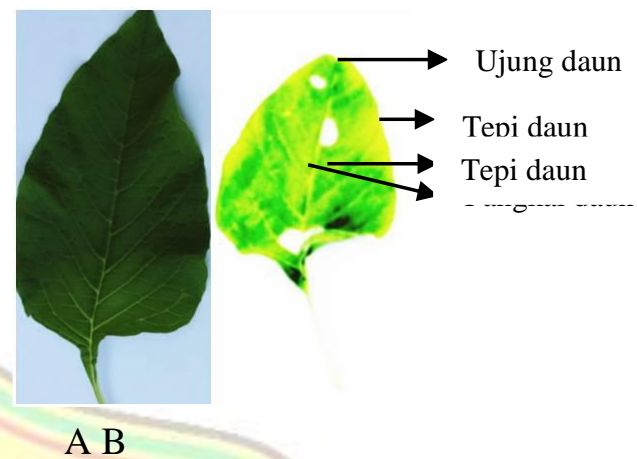

Gambar 2. Gambar Bayam control (a) dan dengan perlakuan diberi 2 ppm $\mathrm{Pb}(\mathrm{b})$.

Pangkal daun berubah dan berbentuk tumpul dengan daging daun yang masih berbentuk tipis lunak. Kerusakan morfologi tersebut terjadi pada saat usia tanaman 3 minggu. Terdapatnya bercakbercak putih pada bagian permukaan daun mengakibatkan daun berlubang/tidak rata dan susunan tulang-tulang daun rusak. Warna daun berubah menjadi hijau kekuningan dan pangkal daun tumpul dan rusak.

Timbal $(\mathrm{Pb})$ sebagian besar diakumulasi oleh organ tanaman, yaitu daun. Perpindahan timbal dari tanah ke tanaman tergantung komposisi dan pH tanah. Konsentrasi timbal yang tinggi (100$1000 \mathrm{mg} / \mathrm{kg}$ ) akan mengakibatkan pengaruh toksik pada proses fotosintesis dan pertumbuhan. Timbal hanya mempengaruhi tanaman bila konsentrasinya tinggi (Widiningrum et al.,2007).

Pemberian $\mathrm{Pb}$ dengan konsentrasi 5 ppm pada tanaman bayam menunjukkan perubahan morfologi secara menyeluruh, diawali dengan munculnya bercak-bercak putih pada permukaan daun, perubahan bentuk ujung daun menjadi tumpul, tepi daun memperlihatkan lekukanlekukan yang menjadikan tidak rata (berombak bahkan sampai membentuk torehan yang agak dala). Lekukan pada pangkal daun tidak sempurna/rusak, begitu juga dengan susunan tulang-tulang daun yang rusak dan putus akibat tidak sempurnanya permukaan dan tepi daun.

Permukaan daun yang tidak rata terjadi akibat timbulnya bercak-bercak putih dalam jumlah yang banyak. Bercak-bercak putih 
tersebut lama kelamaan akan kering dan menyebabkan daun berlubang. Perubahan warna daun menjadi hijau kekuningan. Akibat terjadi perubahan morfologi di atas, maka susunan tulang-tulang daun dan bentuk daun bayam menjadi rusak dan tidak sempurna seperti kondisi tanaman normal biasanya. Kerusakan ini dapat dengan jelas dilihat pada gambar daun bayam kontroldan tanaman yang disemprotkan $\mathrm{Pb} 5 \mathrm{ppm}$ berikut ini:
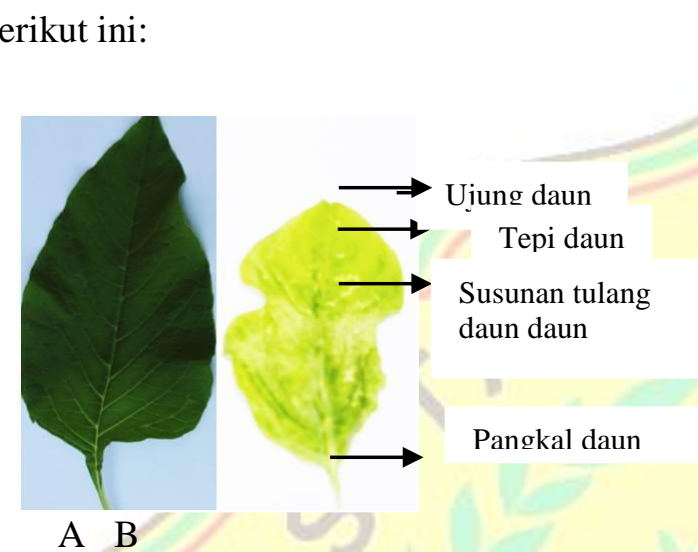

Gambar 3. Gambar daun Bayam control (a) dan denganperlakuan diberi $1 \mathrm{ppm} \mathrm{Pb}(\mathrm{b})$.

Penelitian yang dilakukan oleh Onggo (2006), menunjukkan bahwa pada penyemprotan dengan konsentrasi yang lebih tinggi, 3 hari setelah penyemprotan tampak pada permukaan daun bercak-bercak putih, makin meningkat konsentrasi larutan, gejala kerusakan akan meningkat pula.

Perubahan dengan pemberiankonsentrasi $\mathrm{Pb}$ 5 ppm mengakibatkan perubahan morfologi daun bayam yang ditimbulkan lebih banyak jika dibandingkan pada konsentrasi $\mathrm{Pb} 3$ ppm dan 1 ppm. Pada tanaman kontrol tidak terjadi perubahan atau kerusakan morfologi seperti yang terlihat pada tanaman yang diberi perlakuan $\mathrm{Pb}$. Tinggi rendahnya konsentrasi yang diberikan dapat mempengaruhi banyak sedikitnya atau ada tidaknya perubahan yang ditimbulkan. Hal ini sesuai dengan penelitian Onggo (2006) yang menyatakan bahwa makin meningkat konsentrasi $\mathrm{Pb}$, maka gejala kerusakan makin meningkat pula.

2. Hasil Analisis Kadar Pb pada Daun Bayam

Hasil analisis kadar $\mathrm{Pb}$ pada daun bayam di Laboratorium Kimia Hasil Perikanan Universitas Riau dapat dilihat pada tabel di bawah ini:
Tabel 2. Hasil Analisis Kadar Timbal (Pb) Daun Bayam (denganmenggunakan AAS) pada usia 5 minngu.

\begin{tabular}{cccc}
\hline o & Kode Sampel & $\begin{array}{l}\text { Konsentrasi } \\
\text { Pb (ppm) }\end{array}$ & $\begin{array}{l}\text { Hasil Analisis } \\
(\mathbf{p p m})\end{array}$ \\
\hline & BK & 0 & 0 \\
B1 & 1 & 0,30 \\
B2 & 3 & 0,84 \\
B3 & 5 & 1,13 \\
\hline
\end{tabular}

Keterangan:

BK: Bayam Kontrol

B1 : Bayam 1

B2 : Bayam 2

B3 : Bayam 3

Ppm : Part Per Million

Data dari tabel 2 menunjukkan bahwa pada $\mathrm{B} 3$, kadar $\mathrm{Pb}$ yang dihasilkan lebih tinggi dibandingkan dengan B1 dan B2 yaitu sebesar $1,13 \mathrm{ppm}$. Tingginya kadar $\mathrm{Pb}$ pada $\mathrm{B} 3$ diakibatkan oleh pemberian larutan $\mathrm{Pb}$ yang tinggi $(5 \mathrm{ppm})$. Pemberian larutan $\mathrm{Pb}$ pada konsentrasi 3 ppm memperoleh hasil sebesar 0,84 ppm. Hasil yang diperoleh tersebut lebih rendah dari hasil analisis B3. Hal Ini dikarenakan konsentrasi yang diberikan pada B2 rendah. Hal serupa juga terjadi pada pemberian larutan $\mathrm{Pb}$ pada konsentrasi $1 \mathrm{ppm}$ yang memperoleh hasil analisis sebesar 0,30 ppm. Hal ini dipertegas lagi dalam penelitian yang dilakukan oleh (Onggo, 2006) yang menunjukkan bahwa peningkatan konsentrasi $\mathrm{Pb}$ dalam larutan pada tanaman meningkatkan kadar $\mathrm{Pb}$ dalam tanaman yang disemprotkan begitu juga sebaliknya, ini berarti kadar $\mathrm{Pb}$ pada tanaman tergantung dari tingkat polusinya.

Larutan $\mathrm{Pb}$ yang diberikan dengan cara disemprot akan mengakibatkan tanaman mengakumulasi $\mathrm{Pb}$. Pengakumulasian $\mathrm{Pb}$ tersebut dapat terjadi pada organ tanaman daun. Akumulasi logam timbal $(\mathrm{Pb})$ pada daun akan mempengaruhi masing-masing besarnya kadar $\mathrm{Pb}$ yang dihasilkan. Bayam termasuk salah satu tanaman yang mudah menyerap logam berat dari media tumbuhnya. Penelitian yang dilakukan Kohar et al., (2005), menunjukkan adanya $\mathrm{Pb}$ yang tinggi dalam tanaman yang tumbuh pada media yang terkontaminasi $\mathrm{Pb}$ secara terus menerus (Rumajar, 2010). 


\section{KESIMPULAN}

1. Terjadi perubahan bentuk morfologi daun bayam akibat pemberian timbal $(\mathrm{Pb})$. Perubahan tersebut dapat dilihat pada karakteristik bayam yang meliputi:

a. Pada bayam $\mathrm{Pb} 1 \mathrm{ppm}$, perubahan morfologi yang terjadi hanya pada warna daun dan permukaan daun.

b. Pada bayam $\mathrm{Pb} 3$ ppm dan 5 ppm terjadi perubahan morfologi pada semua karakteristik daun, yaitu pada warna daun, permukaan daun, pangkal daun, ujung daun, tepi daun dan

2. Kadar timbal $(\mathrm{Pb})$ pada B3 (5 ppm) menunjukkan hasil yang tinggi yakni 1,13 ppm, sedangkan B2 (3 ppm) 0,84 ppm dan B1 (1 ppm) 0,30 ppm.

\section{DAFTAR PUSTAKA}

Salkind NJ. Child Development. New York: Macmillan Reference USA; 2002.

Bandini L dan Aziz, 2005, Bayam,Jakarta, Penebar Swadaya.

Cahyadi. W, 2006,"Analisis dan Aspek Kesehatan Bahan Tambahan Pangan", Bumi Aksara, Jakarta.

Charlena, 2004, Pencemaran Logam Berat Timbal $(\mathrm{Pb})$ dan Cadmium $(\mathrm{Cd})$. Pada Sayur-sayuran, Falsafah Sain Program Pascasarjana (S3) Institut, Pertanian Bogor.

Darmono.1995. Logam dalam Sistem Biologi Makhluk Hidup. UI press. Jakarta.

Onggo, T.M, 2006, Jurnal Pengaruh Konsentrasi Larutan Berbagai Senyawa Timbal $(P b)$ Terhadap Kerusakan Tanaman, Hasil dan Beberapa Kriteria Kualitas Sayuran Daun Spinasia, Universitas Padjajaran, Bandung.
I. Kohar, P. H. Hardjo, L. Wijaya, 2005. Jurnal Ilmiah Sains \& Teknologi I. Vol.2.

Rumajar, A.T.B. 2010. Skripsi "Penjajakan Kadar Logam Berat $\mathrm{Pb}$ Pada Tanaman Kangkung Darat (Ipomoea reptans Poir) Asal Kecamatan Medan Deli Dan Kangkung Air (Ipomoea aquatica Forsk) Asal Kecamatan Sunggal Kota Medan”, USU, Medan

Sunarjono. H, 2013, Bertanam 36 Jenis Sayur, Jakarta, Penebar Swadaya.

Suparwoko, 2008, Puring paling Top Serap Timbal, artikel majalah Trubus Online, http://www.trubus-

nline.co.id/mod.php?mod=publisher\&op $=$ viewarticle $\&$ cid $=1 \&$ artid $=1414$ edisi Jumat, Agustus 2008, diakses Februari 2013.

Suharto, 2005, Dampak Pencemaran Logam Timbal $(\mathrm{Pb})$ terhadap tubuh. Efek Toksik Logam. Yogyakarta.

Tafajani. H, 2011, Panduan Komplit Bertanam Sayur dan Buah-buahan, Yogyakarata, Cahaya Atma.

Widiningrum, Miskiyah dan Suismono, 2007, Jurnal pertanian. Ahaya Kontaminasi Logam Berat Dalam Sayuran dan Alternatif Pencegahan Cemarannya, Vol.3, Balai Besar Penelitian dan Pengembangan Pasca Panen Pertanian, Jakarta.

Widowati, 2008. Pencemaran Logam Berat Terhadap Sayuran. Jurnal Sains. Jakarta.

Widowati. H. 2011. Pengaruh Logam Berat Cd, $\mathrm{Pb}$ Terhadap Perubahan Warna Batang dan Daun Sayuran. Jurnal Sains. Vol. 1, No. 4. 